\title{
ANALISIS SISTEM PAKAR UNTUK MENGIDENTIFIKASI PENYAKIT DAN HAMA PADA TANAMAN PADI DENGAN METODE BAYES
}

\author{
${ }^{1}$ Wimar Febrianto, ${ }^{2}$ Alif Hyuda Suryatama, ${ }^{3}$ Novan Afrianto, \\ ${ }^{4}$ Ihwan Mualana, ${ }^{5}$ Prasetyo Nur Hidayat \\ UNIVERSITAS AMIKOM YOGYAKARTA \\ novanworld@gmail.com
}

\begin{abstract}
Abstrak - Padi merupakan hal krusial bagi manusia khususnya orang Indonesia. Sebagian besar penduduk warga Indonesia bekerja pada bidang pertanian umumnya padi. Namun adapun masalah yang banyak dialami para petani padi, yakni penyakit pada padi yang sebagian belum paham cara menentukan ataupun memilih jenis pengobatan yang sesuai dengan penyakit tersebut. Hal ini membuat tingkat produktifitas petani menurun. Sistem pakar berbasis komputer dapat digunakan dalam membantu memecahkan masalah agar petani dapat menentukan pilihan pengobatan. Metode yang diterapkan untuk mengidentifikasi penyakit pada padi adalah Metode Bayes, dimana setiap alternatif yang disediakan akan dilakukan perangkingan untuk memperoleh hasil terbaik. Sistem yang akan dibangun diharapkan mampu membantu petani dalam memilih penanganan yang tepat dan sesuai penyakit pada padi.
\end{abstract}

Kata Kunci : Padi, Bayes, Sistem pakar.

\section{PENDAHULUAN}

Petani di Indonesia yang ahli pada bidang penyakit tanaman padi masih terbatas dalam menyelesaikan serangan hama dan penyakit yang menyerang. Hal tersebut dibuktikan banyaknya petani yang melakukan kesalahan dalam cara pengobatan padi yang terserang penyakit. Diharapkan dengan pembuatan sistem pakar untuk mendiagnosa penyakit tanaman padi ini dapat membantu petani untuk mengatasi permasalahan dan memberikan solusi yang terbaik. Proses pembuatan sistem pakar ini menggunakan metode kepastian Bayes, dimana metode ini didasarkan dari kondisi awal yang merupakan kondisi dimana gejala-gejala yang ada kemudian dikenakan aturan yang sudah ditentukan lalu diambil nilai kebenaran yang paling besar untuk menentukan solusi dari gejala yang disebutkan sebelumnya.

Adapun penelitian sistem pakar yang pernah penulis baca adalah Identifikasi Penyakit pada Tanaman Kedelai Menggunakan Metode Classical Probability. Namun penelitian sistem pakar tersebut hanya mendeteksi hama pada tanaman kedelai tanpa pembuatan jenis penyakit yang terdeteksi, berbeda dengan sistem pakar menggunakan Metode Bayes ini yang dimanfaatkan untuk mengidentifikasi penyakit pada padi dan gejala-gejala yang menyebabkan penyakit tersebut. Berdasarkan uraian diatas, penulis tertarik membuat analisis tentang sistem pakar dengan harapan dapat bermanfaat bagi masyarakat petani dalam mengelola padi serta meningkatkan hasil panen warga.

\section{TINJAUAN PUSTAKA}

\section{A. Sistem Pakar}

Sistem pakar adalah aplikasi berbasis komputer untuk menyelesaikan suatu masalah sehari-hari sebagaimana halnya seperti yang dilakukan oleh seorang pakar (Kusrini, 2008).

Sistem pakar merupakan sistem yang berbasis computer menggunakan pengetahuan, fakta, serta teknik penalaran dalam memecahkan suatu masalah yang biasanya hanya bias dipecahkan oleh seorang pakar di bidang tersebut.

Sistem pakar adalah sistem informasi berbasis computer yang menggunakan pengetahuan pakar untuk mencapai performa keputusan tingkat tinggi dalam domain persoalan yang sempit. Bagian dalam sistem 
pakar terdiri dari 2 komponen utama, yakni berisi knowledge base yang merupakan basis pengetahuan dan mesin inferensi yang menggambarkan kesimpulan. Kesimpulan tersebut merupakan respon dari sistem pakar terhadap permintaan pengguna.

Gambar berikut menunjukkan konsep dasar dari suatu sistem pakar.

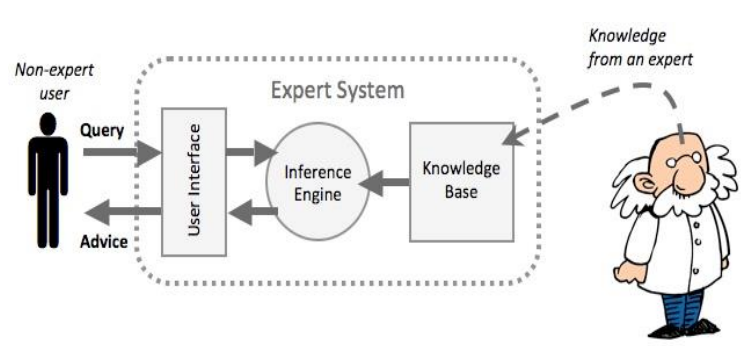

Gambar 2.1 Konsep Dasar Sistem Pakar

1. Basis Pengetahuan (Knowledge Base) merupakan inti dari suatu sistem pakar, adalah representasi pengetahuan dari pakar yang sesungguhnya. Basis pengetahuan tersusun dari fakta dan kaidah.

2. Mesin Inferensi (Inference Engine) berperan sebagai otak dari sistem pakar. Mesin Inferensi berfungsi untuk memandu proses penalaran terhadap suatu kondisi berdasarkan basis pengetahuan yang tersedia. Di dalam mesin inferensi terjadi proses untuk memanipulasi dan mengarahkan kaidah dan fakta yang disimpan dalam basis pengetahuan dalam rangka mencapai solusi atau kesimpulan yang tepat. Dalam prosesnya, mesin inferensi mmenggunakan strategi penalaran dan pengendalian. Strategi penalaran terdiri dari strategi penalaran pasti (Exact Reasoning) dan strategi penalaran tidak pasti (Inexact Reasoning). Exact Reasoning akan dilakukan jika semua data yang dibutuhkan untuk menarik suatu kesimpulan tersedia, sedangkan Inexact Reasoning dilakukan saat data yang dibutuhkan hanya terdiri dari sebagian data yang dibutuhkan. Strategi Pengendalian berfungsi sebagai pemandu arah dalam melakukan proses penalaran. Terdapat 3 teknik yang sering digunakan, yaitu forward chaining, backward chaining dan gabungan dari keduanya.

3. Antarmuka Pemakai (User Interface) merupakan fasilitas yang digunakan sebagai perantara komunikasi antara pemakain dengan computer.

\section{B. Metode Bayes}

Metode Bayes adalah salah satu metode untuk mengatasi ketidakpastian suatu data, yang kemudian dapat dirumuskan dalam persamaan bayes sebagai berikut;

$$
P(H \mid E)=\frac{P(E \mid H) \cdot P(H)}{P(E)}
$$

Keterangan :

$\mathrm{P}(\mathrm{H} \mid \mathrm{E})$ : Probabilitas hipotesa $\mathrm{H}$ jika diketahui evidence $\mathrm{E}$.

$P(E \mid H)$ : Probabilitas munculnya evidence $E$ jika diketahui hipotesa $\mathrm{H}$.

$\mathrm{P}(\mathrm{H}) \quad$ : Probabilitas hipotesa $\mathrm{H}$ tanpa memandang evidence apapun.

$\mathrm{P}(\mathrm{E}) \quad$ : Probabilitas evidence $\mathrm{E}$ tanpa memandang apapun.

\section{Hama}

Dalam pertanian, hama adalah organisme pengganggu tanaman (OPT) yang menimbulkan kerusakan secara fisik, dan kedalamnya praktis adalah semua hewan yang menyebabkan kerugian dalam pertanian.

\section{Penyakit Tanaman}

Penyakit tanaman adalah gangguan pada tanaman yang disebabkan oleh mikroorganisme. jasad patogen yang biasa menyebabkan tanaman menjadi sakit adalah jenis jamur atau cendawan, bakteri, virus, protozoa, nematoda dan lain lain. pada beberapa kajian, nematoda dikategorikan sebagai hama karena cara merusaknya sama dengan hama. namun di beberapa literatur lain nematoda dapat dikategorikan penyakit tanaman karena nematoda termasuk kedalam kelompok mikroorganisme.

\section{PERANCANGAN}

Pada tahap ini, nilai probabilitas penyakit dihitung sesuai dengan gejala yang dipilih. 


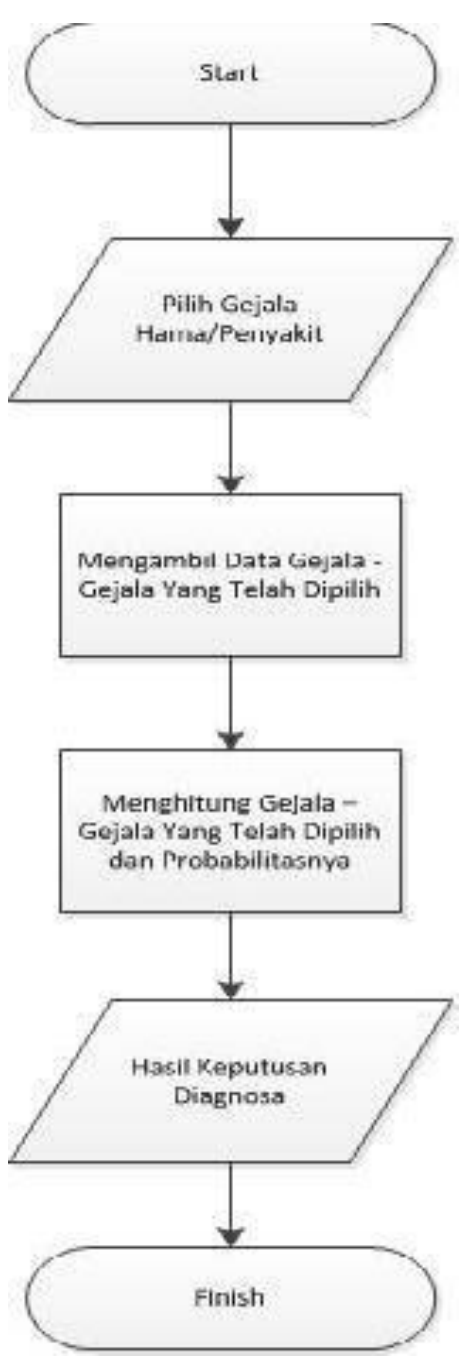

Gambar 3.1 Flowchart Bayes

Keterangan:

1. Pilih gejala sebagai proses identifikasi awal.

2. Mengambil data sesuai dengan gejala yang dipilih.

3. Hitung probabilitas menggunakan metode Bayes setiap gejala yang dipilih sesuai kejadian yang dialami.

4. Hasil diagnosa dipilih dari nilai probabilitas Bayes yang tertinggi

\section{HASIL DAN PEMBAHASAN}

\section{Tabel data penyakit}

\begin{tabular}{|c|l|}
\hline $\begin{array}{c}\text { Kode } \\
\text { Penyakit }\end{array}$ & Nama Penyakit \\
\hline P01 & Hawar daun \\
\hline P02 & Kerdil \\
\hline P03 & Tungro \\
\cline { 1 - 2 }
\end{tabular}

\begin{tabular}{|l|l|}
\hline P04 & Leaf streak \\
\hline P05 & Bercak coklat \\
\hline P06 & WBC \\
\hline P07 & Blast \\
\hline P08 & Penggerek batang \\
\hline P09 & Wereng hijau \\
\hline
\end{tabular}

Tabel 4.1 Data penyakit

\section{Tabel data gejala}

\begin{tabular}{|c|c|}
\hline $\begin{array}{l}\text { Kode } \\
\text { Gejala }\end{array}$ & Nama Gejala \\
\hline G01 & Menyerang daun titik tumbuh \\
\hline G02 & $\begin{array}{l}\text { Terdapat garis-garis diantara tulang } \\
\text { daun }\end{array}$ \\
\hline G03 & $\begin{array}{l}\text { Terdapat garis basah berwarna } \\
\text { merah kekuningan pada helai daun } \\
\text { sehingga daun seperti terbakar }\end{array}$ \\
\hline G04 & $\begin{array}{l}\text { Bercak tersebar merata pada } \\
\text { permukaan daun }\end{array}$ \\
\hline G05 & $\begin{array}{l}\text { Daun menjadi pendek, sempit, } \\
\text { berwarna hijau kekuning-kuningan }\end{array}$ \\
\hline G06 & Batang pendek \\
\hline G07 & $\begin{array}{l}\text { Pertumbuhan tanaman kurang } \\
\text { sempurna }\end{array}$ \\
\hline G08 & Buku-buku pendek \\
\hline G09 & Daun kuning hingga kecoklatan \\
\hline G10 & Anakan banyak tetapi kecil \\
\hline G11 & Jumlah tunas berkurang \\
\hline G12 & Pembungaan tertunda \\
\hline G13 & Malai kecil dan tidak berisi \\
\hline G14 & Anakan berkurang atau sedikit \\
\hline G15 & $\begin{array}{l}\text { Daun berubah menjadi kuning } \\
\text { sampai kuning oranye }\end{array}$ \\
\hline G16 & Akar tanaman lebih sedikit \\
\hline G17 & Anakan bertambah banyak \\
\hline G18 & Daun berwarna kuning pucat \\
\hline G19 & $\begin{array}{l}\text { Bercak pada pelepah daun bagian } \\
\text { bawah }\end{array}$ \\
\hline $\mathrm{G} 20$ & Daun berwarna abu-abu kehijauan \\
\hline G21 & Malai tanaman kering atau mati \\
\hline G22 & Daun bercak warna hijau pucat \\
\hline G23 & Terdapat bercak pada tepi daun \\
\hline G24 & $\begin{array}{l}\text { Tanaman mudah dicabut dari } \\
\text { anakan }\end{array}$ \\
\hline G25 & $\begin{array}{l}\text { Adanya bekas lubang pada } \\
\text { pelepah daun dan batang }\end{array}$ \\
\hline G26 & $\begin{array}{l}\text { Terdapat telur pada pelepah daun } \\
\text { dan tulang daun }\end{array}$ \\
\hline
\end{tabular}

Tabel 4.2 Data gejala

\section{Basis Pengetahuan}

Berikut ini adalah merupakan beberapa contoh basis pengetahuan yang dijadikan 
sebagai referensi penerapan teorema Bayes dalam menentukan probabilitas penyakit berdasarkan gejala yang dialami dengan menggunakan kode untuk masing-masing penyakit dan gejala.

\section{Penyakit (P01) : Hawar daun}

\section{Gejala :}

G01 | Menyerang daun dan titik tumbuh G02 | Terdapat garis-garis diantara tulang daun

Penanganan : menanam varitas tahan penyakit seperti IR36, IR46, Cisadane, Cipunegara; menghindari luka mekanis, sanitasi lingkungan, pengendalian kimia dengan bakterisida Stablex WP.

Penyakit (P02) : Kerdil

\section{Gejala :}

G05 | Daun menjadi pendek, sempit, berwarna hijau kekuning-kuningan

G06 | Batang pendek

G08 | Buku-buku pendek

G10 | Anakan banyak tetapi kecil

Penanganan : sulit dilakukan, usaha pencegahan dilakukan dengan memusnahkan tanaman yang terserang.

Penyakit (P03) : Tungro

\section{Gejala :}

G07 | Pertumbuhan tanaman kurang sempurna

G09 | Daun kuning hingga kecoklatan

G11 | Jumlah tunas berkurang

G12 | Pembungaan tertunda

G13 | Malai kecil dan tidak berisi

Penanganan : menanam padi tahan wereng seperti Kelara, IR52, IR36, IR48, IR54, IR46, IR42 (A.W, Imam; 2005: 30).

Penyakit (P04) : Leaf streak

\section{Gejala :}

G01 | Menyerang daun dan titik tumbuh G03 | Terdapat garis basah berwarna merah kekuningan pada helai daun sehingga daun seperti terbakar
Penanganan : menanam varitas unggul, menghindari luka mekanis, pergiliran varitas dan bakterisida Stablex 10 WP.

\section{Penghitungan Manual Dalam Suatu Masalah}

Misalkan gejala yang terdeteksi pada tanaman padi ada 2 Gejala; yaitu G01 dan G03

1. Hitung Penyakit Hawar daun (P01);

Jika probabilitas P01 adalah : 0,11

Jika probabilitas memandang penyakit adalah G01 : 0,3

G03 : 0

Perhitungan nilai Bayes:

$$
\begin{aligned}
& \mathrm{P}(\mathrm{P} 01 \mid \mathrm{G} 01) \quad \mathrm{P}(\mathrm{G} 01 \mid \mathrm{P} 01) * \mathrm{P}(\mathrm{P} 01) \\
& =\overline{\mathrm{P}(\mathrm{G} 01 \mid \mathrm{P} 01) * \mathrm{P}(\mathrm{P} 01)+\mathrm{P}(\mathrm{G} 01 \mid \mathrm{P} 02) * \mathrm{P}(\mathrm{P} 02)+\mathrm{P}(\mathrm{G} 01 \mid \mathrm{P} 03) * \mathrm{P}(\mathrm{P} 03)+}
\end{aligned}
$$

Total Bayes $1=0,5+0=0,5$

2. Hitung penyakit Kerdil (P02);

Jika probabilitas P02 adalah : 0,11

Jika probabilitas memandang penyakit adalah

G01 : 0

G03 : 0

Perhitungan nilai Bayes:

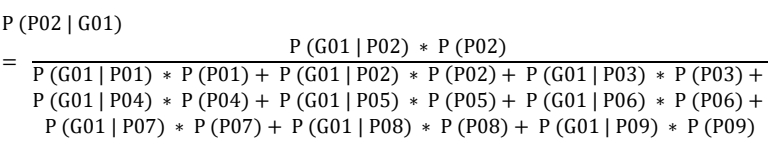




$$
\begin{aligned}
= & \frac{0 * 0,11}{(0,3 * 0,11)+(0 * 0,11)+(0 * 0,11)+} \\
& (0,3 * 0,11)+(0 * 0,11)+(0 * 0,11)+ \\
& (0 * 0,11)+(0 * 0,11)+(0 * 0,11) \\
= & \frac{0}{0,066}=0
\end{aligned}
$$

$$
\begin{aligned}
& \mathrm{P}(\mathrm{P} 02 \mid \mathrm{G} 03) \\
& \mathrm{P}(\mathrm{G} 03 \mid \mathrm{P} 02) * \mathrm{P}(\mathrm{P} 02) \\
& =\frac{0 * 0,11}{(0,3 * 0,11)+(0 * 0,11)+(0 * 0,11)+} \\
& (0,3 * 0,11)+(0 * 0,11)+(0 * 0,11)+ \\
& (0 * 0,11)+(0 * 0,11)+(0 * 0,11) \\
& =\frac{0}{0,066}=0
\end{aligned}
$$

$=\overline{\mathrm{P}(\mathrm{G} 03 \mid \mathrm{P} 01) * \mathrm{P}(\mathrm{P} 01)+\mathrm{P}(\mathrm{G} 03 \mid \mathrm{P} 02) * \mathrm{P}(\mathrm{P} 02)+\mathrm{P}(\mathrm{G} 03 \mid \mathrm{P} 03) * \mathrm{P}(\mathrm{P} 03)+}$ $\mathrm{P}(\mathrm{G} 03 \mid \mathrm{P} 04) * \mathrm{P}(\mathrm{P} 04)+\mathrm{P}(\mathrm{G} 03 \mid \mathrm{P} 05) * \mathrm{P}(\mathrm{P} 05)+\mathrm{P}(\mathrm{G} 03 \mid \mathrm{P} 06) * \mathrm{P}(\mathrm{P} 06)+$ $\mathrm{P}(\mathrm{G} 03 \mid \mathrm{P} 07) * \mathrm{P}(\mathrm{P} 07)+\mathrm{P}(\mathrm{G} 03 \mid \mathrm{P} 08) * \mathrm{P}(\mathrm{P} 08)+\mathrm{P}(\mathrm{G} 03 \mid \mathrm{P} 09) * \mathrm{P}(\mathrm{P} 09)$

Total Bayes 2 $=0+0=0$

3. Hitung Penyakit Tungro (P03);

Jika probabilitas P03 adalah : 0,11

Jika probabilitas memandang penyakit adalah

G01 : 0

G03 : 0

Perhitungan nilai Bayes:

$$
\begin{aligned}
& \text { P (P03 | G01) } \\
& =\frac{\mathrm{P}(\mathrm{G} 01 \mid \mathrm{P} 03) * \mathrm{P}(\mathrm{P} 03)}{\mathrm{P}(\mathrm{G} 01 \mid \mathrm{P} 01) * \mathrm{P}(\mathrm{P} 01)+\mathrm{P}(\mathrm{G} 01 \mid \mathrm{P} 02) * \mathrm{P}(\mathrm{P} 02)+\mathrm{P}(\mathrm{G} 01 \mid \mathrm{P} 03) * \mathrm{P}(\mathrm{P} 03)+} \\
& \mathrm{P}(\mathrm{G} 01 \mid \mathrm{P} 04) * \mathrm{P}(\mathrm{P} 04)+\mathrm{P}(\mathrm{G} 01 \mid \mathrm{P} 05) * \mathrm{P}(\mathrm{P} 05)+\mathrm{P}(\mathrm{G} 01 \mid \mathrm{P} 06) * \mathrm{P}(\mathrm{P} 06)+ \\
& \mathrm{P}(\mathrm{G} 01 \mid \mathrm{P} 07) * \mathrm{P}(\mathrm{P} 07)+\mathrm{P}(\mathrm{G} 01 \mid \mathrm{P} 08) * \mathrm{P}(\mathrm{P} 08)+\mathrm{P}(\mathrm{G} 01 \mid \mathrm{P} 09) * \mathrm{P}(\mathrm{P} 09) \\
& =\frac{0 * 0,11}{(0,3 * 0,11)+(0 * 0,11)+(0 * 0,11)+} \\
& (0 * 0,11)+(0 * 0,11)+(0 * 0,11) \\
& =\frac{0}{0,066}=0 \\
& \mathrm{P} \text { (P03 | G03) } \\
& =\frac{\mathrm{P}(\mathrm{G} 03 \mid \mathrm{P} 03) * \mathrm{P}(\mathrm{P} 03)}{\mathrm{P}(\mathrm{G} 03 \mid \mathrm{P} 01) * \mathrm{P}(\mathrm{P} 01)+\mathrm{P}(\mathrm{G} 03 \mid \mathrm{P} 02) * \mathrm{P}(\mathrm{P} 02)+\mathrm{P}(\mathrm{G} 03 \mid \mathrm{P} 03) * \mathrm{P}(\mathrm{P} 03)+} \\
& \mathrm{P}(\mathrm{G} 03 \mid \mathrm{P} 04) * \mathrm{P}(\mathrm{P} 04)+\mathrm{P}(\mathrm{G} 03 \mid \mathrm{P} 05) * \mathrm{P}(\mathrm{P} 05)+\mathrm{P}(\mathrm{G} 03 \mid \mathrm{P} 06) * \mathrm{P}(\mathrm{P} 06)+ \\
& \mathrm{P}(\mathrm{G} 03 \mid \mathrm{P} 07) * \mathrm{P}(\mathrm{P} 07)+\mathrm{P}(\mathrm{G} 03 \mid \mathrm{P} 08) * \mathrm{P}(\mathrm{P} 08)+\mathrm{P}(\mathrm{G} 03 \mid \mathrm{P} 09) * \mathrm{P}(\mathrm{P} 09) \\
& =\frac{0 * 0,11}{(0,3 * 0,11)+(0 * 0,11)+(0 * 0,11)+} \\
& (0 * 0,11)+(0 * 0,11)+(0 * 0,11) \\
& =\frac{0}{0,066}=0
\end{aligned}
$$

Total Bayes 3 $=0+0=0$

4. Hitung Penyakit Leaf streak (P04);

Jika probabilitas P04 adalah : 0,11

Jika probabilitas memandang penyakit adalah

G01 : 0,3

$\mathrm{G} 03: 0,3$

Perhitungan nilai Bayes:

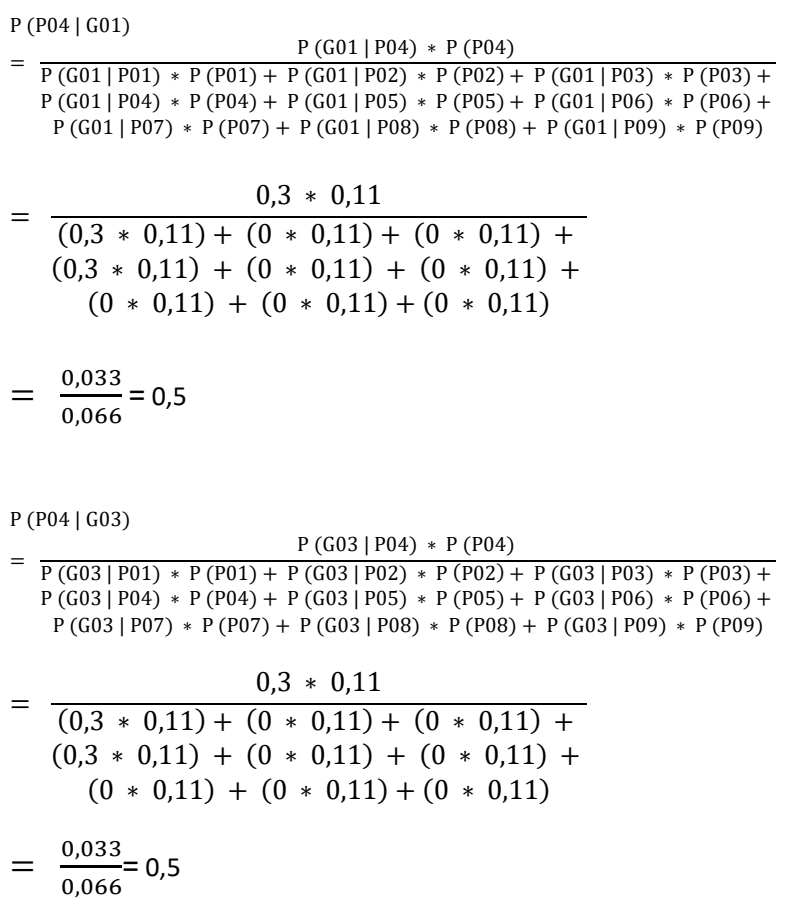

Total Bayes $4=0,5+0,5=1$

Maka perhitungan probabilitas penyakitnya adalah;

1. Penyakit Hawar daun (P01), $0,5 * 100 \%=50 \%$

2. Penyakit Kerdil (P02), $0 * 100 \%=0 \%$

3. Penyakit Tungro (P03), $0 * 100 \%=0 \%$

4. Penyakit Leaf streak (P04), $1 * 100 \%=100 \%$

Jadi tanaman padi tersebut mengalami penyakit Leaf streak (P04).

Penanganan yang sesuai adalah menanam varitas unggul, menghindari luka mekanis, pergiliran varitas dan bakterisida Stablex 10 WP.

\section{KESIMPULAN}

Berdasarkan uraian yang telah dikemukakan oleh penulis, maka penulis mengambil kesimpulan yaitu :

1. Dengan menggunakan metode teorema bayes dapat mengindentifikasi penyakit tanaman padi dengan menggunakan persentase gejala tanaman.

2. Dengan adanya Sistem Pakar menggunakan metode teorema bayes dapat menghitung persentase besar kemungkinan penyakit 
padi yang dialami petani sehingga petani

dapat dengan mandiri melakukan penanganan yang tepat.

3. Untuk implementasi kedalam aplikasi, aplikasi hanya dapat mengidentifikasi gejala yang tampak secara umum. Disarankan menggunakan data sample yang lebih besar agar hasil identiikasi lebih akurat.

\section{DAFTAR PUSTAKA}

[1] Anum, R. 2013. Identifikasi Penyakit pada Tanaman Kedelai Menggunakan Metode Classical Probability. Malang: Universitas Brawijaya

[2] Arhami, M. 2005. Konsep Dasar Sistem Pakar. Yogyakata: Andi

[3] Kusumadewi, S. 2003. Artificial Intelegence (Teknik dan Aplikasinya). Yogyakarta: Graha IImu

[4] Tuti, E. 2015. Penerapan Teorema Bayes Pada Sistem Pakar Untuk Mengidentifikasi Penyakit Tumbuhan. Medan: Universitas Potensi Utama 